\title{
The development plan of the low-carbon island, Penghu
}

\author{
P.-H. Li ${ }^{1}$, M.-L. Hung ${ }^{1} \&$ W.-C. Chiang ${ }^{2}$ \\ ${ }^{I}$ Green Energy and Environment Research Laboratories, \\ Industrial Technology Research Institute, ROC \\ ${ }^{2}$ Bureau of Energy, Ministry of Economic Affairs, ROC
}

\begin{abstract}
The Ministry of Economic Affairs, R.O.C. chooses Penghu Island as a pilot case to illustrate the strategies to establish a low-carbon society in Taiwan. A greenhouse gas inventory based procedure has been proposed to determine a proper development plan. In view of the abundant wind resource of the Penghu Island, wind energy is adopted as the major measure to reduce about $50 \%$ of the total greenhouse gas emissions in Penghu Island. Moreover, to construct a sustainable living environment, resources recycling, multisource water supply, zero-waste management and other approaches are also considered. This project will be completed in 5 years (from 2011 to 2015), and the total amount of budget is about 8.09 billion TWD ( 270 million USD). The low-carbon island project comprises eight aspects, including renewable energy, energy saving, green transportation, low-carbon building, forestation, resource recycling, low-carbon life and low-carbon education. After the completion of this project, the generated electricity from renewable energy will exceed electricity consumption in Penghu Island, and carbon emission per capita every year will be reduced to 2.1 tons$\mathrm{CO}_{2} \mathrm{e} /$ year from 5.4 tons- $\mathrm{CO}_{2} \mathrm{e} /$ year. The applications of renewable energy and other carbon reduction strategies in this project can be an ideal study case for achieving a low-carbon society in other areas.
\end{abstract}

Keywords: renewable energy, wind power, island, carbon reduction.

\section{Introduction}

In recent years, climate change and carbon abatement are the most concerned issues in the global society. Governments around the world are working hard to 
find ways to reduce greenhouse gas (GHG) emissions On World Environment Day, 2009, The Administrative Yuan of the R.O.C. government approved a set of guidelines named "Framework of the Sustainable Energy Policy", declaring its intention to develop renewable energy and reduce GHG emissions The Administrative Yuan also laid out a comprehensive plan, "Energy Saving and Carbon Reduction Master Plan," in 2010 aiming to reduce the country's GHG emission to 2005 level by 2020 .

The Third National Energy Conference was thus held in 2009 to address how to achieve the carbon reduction target, and concluded that the low carbon society should be one of the major approaches. Counties in Taiwan should establish at least two low carbon communities by 2012. Six low carbon cities will be established by 2016. Eventually, four districts of Taiwan, including Northern, Middle, Southern, and Eastern districts, will be transformed into low carbon societies by 2020 .

Although there are many low-carbon development plans underway all over the world, such as eco-model cities in Japan [1] and Jeju Island in Korea [2], there is still lack of a systematic approach for a central government to transform a nation-wide greenhouse gas (GHG) emissions reduction target into a solid implementation plan for a local government to reduce GHG emissions in various sectors.

The Ministry of Economic Affairs, Taiwan (ROC), hence, chooses Penghu Island as a pilot area to build the country's first low-carbon community. A systematic procedure is proposed to identify the major sources of GHG emissions, and a proper plan for a local government is then determined to implement the GHG reduction tasks. The Penghu Low Carbon Island project is formulated based on the procedure. The project will be carried out from 2011 to 2015. In the following sections, the background information of Penghu Island is first introduced. The development procedure for the low-carbon island project is then addressed, followed by the details and benefits of the proposed plans.

\section{Penghu Island}

Penghu Island locates on Taiwan Strait between China and Taiwan, as illustrated in fig. 1. Penghu County is an island county of Taiwan and comprises about 90 isles scattered between north latitude $23^{\circ} 12^{\prime}$ to $23^{\circ} 47^{\prime}$ and east longitude $119^{\circ} 19^{\prime}$ to $119^{\circ} 43^{\prime}$. The major island is the Penghu Island which area is about $127 \mathrm{~km}^{2}$. The Penghu Island is comprised of three most populous islands, including Magong City/Husi Township, Baisha Township, and Siyu Township, which are connected by bridges to form the main island. The population is about 96,918 in 2011. Fishery is the largest industry with annual revenue of about NT\$ 3 billion ( $\sim 100$ million USD), and tourism is the second industry with annual revenue of about NT\$ 2 billion ( $\sim 67$ million USD). There are 665,978 tourists visited Penghu Island from Taiwan and other countries in 2011. Most tourists traveled to Penghu Island by airplane via Taiwan. 


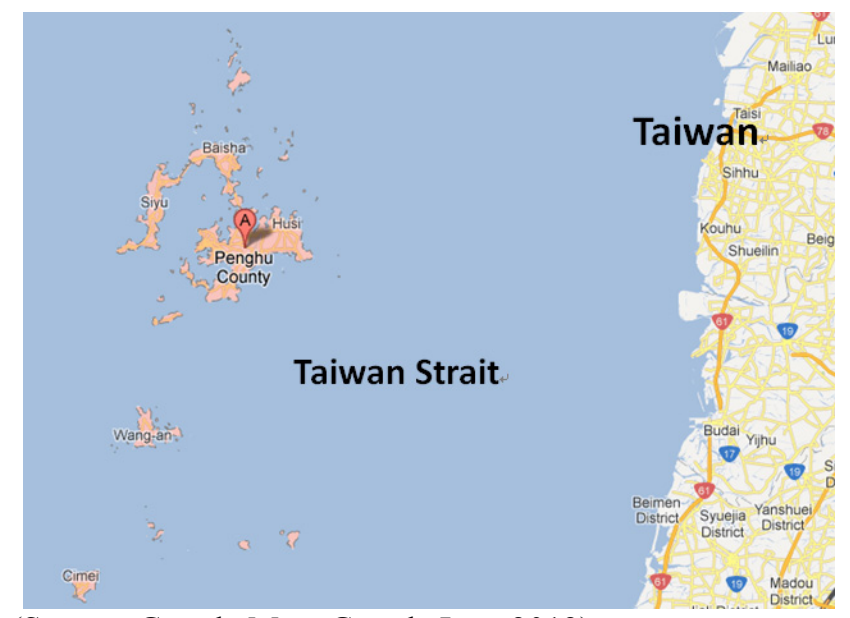

(Source: Google Map, Google Inc., 2012)

Figure 1: Geographic location of Penghu Island.

Greenhouse gas emissions are majorly contributed by consuming fossil fuels. Therefore, it is critical to identify the structure of energy consumption in Penghu Island. As shown in fig. 2, over half of the energy consumption is supplied by heavy oil for electricity generation at a power station. The second largest consumption of energy is diesel for fishery since it is the largest industry. The rest of energy is consumed by transportation. There is already a wind farm with $5.4 \mathrm{MW}$ in operation and providing about $1 \%$ of the energy supply.

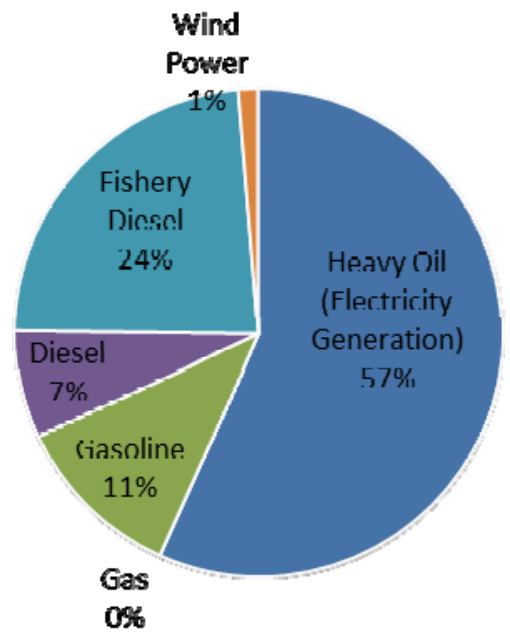

Figure 2: $\quad$ Energy supply structure of Penghu Island. (ITRI 2010). 
Besides, Penghu Island has several superior conditions for developing lowcarbon plans and thus is chosen as a pilot island. Three major advantages are listed as follows.

- Ideal wind field: average wind speed is $9.6 \mathrm{~m} / \mathrm{s}$, and wind turbines can operate in full capacity for about 3,800 hours every year.

- Sufficient solar energy: solar panel can operate in full capacity for about 1,700 hours every year.

- Tourism hotspot: more than 60,000 tourists every year.

\section{Planning procedure}

To develop a reliable, economic and efficient implementation plan to reduce the GHG emissions in Penghu Island, a GHG inventory based development procedure for carbon reduction is proposed in this study, as illustrated in fig. 3. Consumptions of primary energy in each sector are investigated first. Based on the collected information, the GHG emissions of each sector are evaluated by the methods suggested by ICLEI [3] and IPCC [4]. The major sources of GHG emissions can then be identified. All possible measures for GHG reduction in each sector are considered simultaneously, and the most proper measures are selected. The final plan can be formulated by integrating all efficient approaches under specific budget and available resources.

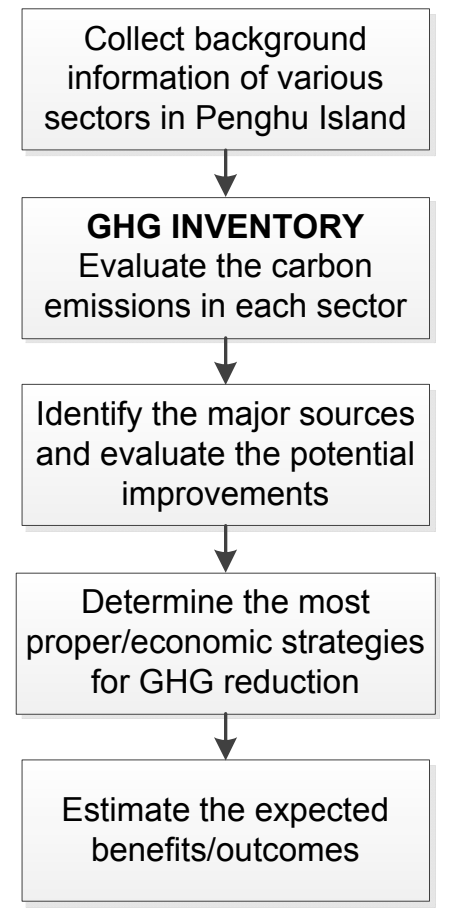

Figure 3: $\quad$ Flowchart of plan development. 


\section{Greenhouse gas inventory}

After a complete survey and investigation, energy consumed by every sector in Penghu Island is collected. According to the usage of different kind of fossil fuels, the emission factors vary considerably. The evaluation procedure also differs for each kind of fuels used on different purposes. The evaluation methods suggested by ICLEI [3] and IPCC [4] are adopted in this study. The GHG inventory result is presented in table 1 and fig. 4 .

Table 1: $\quad$ GHG inventory result of Penghu Island in 2011.

\begin{tabular}{|c|c|c|c|c|c|c|}
\hline \multicolumn{2}{|c|}{ Sector } & \multirow[t]{2}{*}{ Source } & \multicolumn{2}{|c|}{ Scope 1} & \multicolumn{2}{|c|}{ Scope 2} \\
\hline & & & $\begin{array}{c}\text { Emission } \\
\text { (tons- } \\
\mathrm{CO}_{2} e \text { ) } \\
\end{array}$ & Ratio & $\begin{array}{c}\text { Emission } \\
\text { (tons- } \\
\mathrm{CO}_{2} e \text { ) } \\
\end{array}$ & Ratio \\
\hline \multirow{11}{*}{ 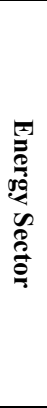 } & Power Station & Fossil Fuel & 254,627 & $45.0 \%$ & - & - \\
\hline & Industry & Electricity & - & - & 13,010 & $5.1 \%$ \\
\hline & \multirow[t]{2}{*}{ Commercial } & $\begin{array}{c}\text { liquefied petroleum } \\
\text { gas(LPG) }\end{array}$ & 15,120 & $2.7 \%$ & - & - \\
\hline & & Electricity & - & - & 196,780 & $77.3 \%$ \\
\hline & \multirow[t]{5}{*}{ Transportation } & Gasoline & 53,570 & $9.5 \%$ & - & - \\
\hline & & Diesel & 58,488 & $10.3 \%$ & - & - \\
\hline & & Coolant & 19,244 & $3.4 \%$ & - & - \\
\hline & & Ferry & 155,882 & $27.5 \%$ & - & - \\
\hline & & Total & 287,185 & $50.7 \%$ & - & - \\
\hline & \multirow[t]{2}{*}{ Building } & Fossil Fuel & 1,672 & $0.3 \%$ & - & - \\
\hline & & Electricity & & & 44,837 & $17.6 \%$ \\
\hline \multicolumn{3}{|c|}{ Total for Energy Sector } & 558,606 & $98.7 \%$ & 254,627 & \\
\hline & ustrial Process & Process & - & - & & \\
\hline \multirow{3}{*}{\multicolumn{2}{|c|}{ Agriculture }} & Animal Intestines & 2,070 & $0.4 \%$ & & \\
\hline & & Animal Manure & 143 & $0.0 \%$ & & \\
\hline & & Total & 2,213 & $0.4 \%$ & & \\
\hline \multirow{3}{*}{\multicolumn{2}{|c|}{ Waste }} & Incineration & 0 & $0.0 \%$ & & \\
\hline & & Septic Tank & 5,365 & $0.9 \%$ & & \\
\hline & & Total & 5,365 & $0.9 \%$ & & \\
\hline \multicolumn{3}{|c|}{ Total } & 566,184 & $100.0 \%$ & & \\
\hline & Forest & Sequestration & $-1,332$ & $-0.2 \%$ & & \\
\hline \multicolumn{3}{|c|}{ Total } & 564,851 & $99.8 \%$ & & \\
\hline \multicolumn{3}{|c|}{$\begin{array}{c}\begin{array}{c}\text { Average Emission per capita } \\
\text { (tons-CO }-\mathrm{C}_{2} \mathrm{e} / \text { cap-yr) }\end{array} \\
\end{array}$} & 6.37 & & & \\
\hline
\end{tabular}

As shown in table 1 and fig. 4, the total GHG emission is about 564,851 tons$\mathrm{CO}_{2} \mathrm{e} /$ year. There are two scopes listed in table 1. Scope 1 indicates those GHG emissions from using primary energies, and scope 2 presents GHG emissions from using secondary energy, such as electricity. According to the result of scope 1, there are two major sources of GHG emissions, including electricity generation at the only power station and transportation. As also shown in fig. 2, electricity generation consumed over half of the total energy supply for Penghu Island. It thus releases about $45 \%$ of $\mathrm{GHG}$ emission from combustion procedure at the power station. Although transportation sector consumed about $42 \%$ energy 
supply, the GHG emission from transportation is about $50.7 \%$ which is much higher than that from energy sector. This could be the combustion efficiency is worse in vehicles, motorbikes and fishing boats. The GHG emission factor of transportation is thus higher than that at the power station. The third major source of GHG emission is commercial activities, which release about $2.7 \%$ GHG from using LPG.

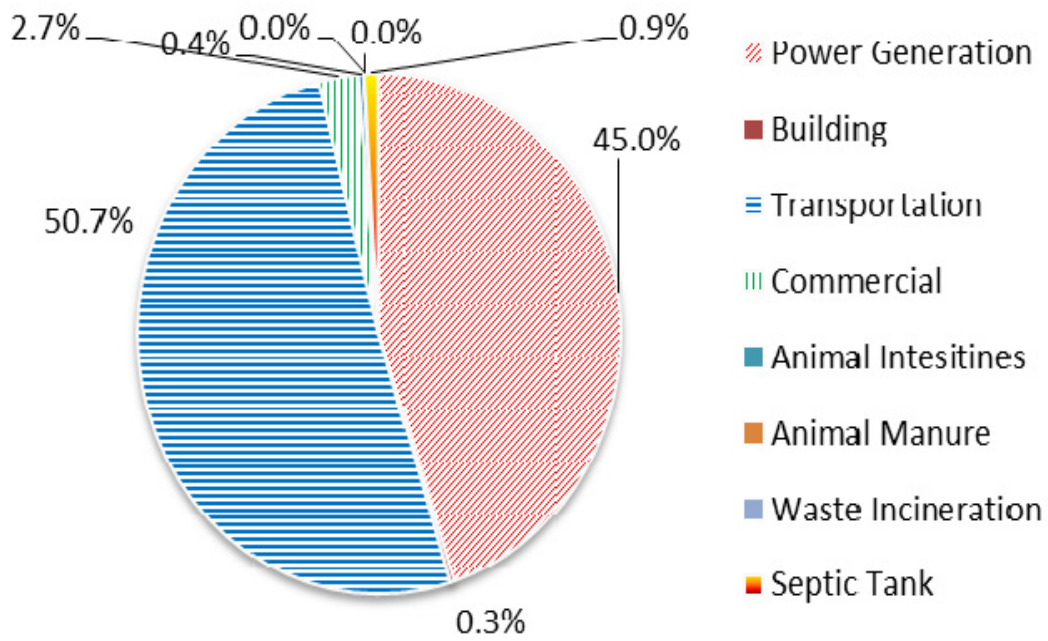

Figure 4: Ratios of GHG emissions from various sources.

\section{The low-carbon island plan}

According to the GHG inventory result, the first two major sources of GHG emissions are electricity generation and transportation, which account for about 95.7\% of GHG emissions in Penghu Island. Therefore, proper strategies should be adopted to reduce GHG emissions from these major sources.

Since Penghu Island locates on Taiwan Strait between China and Taiwan, wind speed accelerates when wind blows through the strait. Penghu Island is thus a windy island. The annual average wind speed is $9.6 \mathrm{~m} / \mathrm{s}$. For six months each year starting in October, Penghu's strong northeast monsoon blows at more than $12 \mathrm{~m} / \mathrm{s}$ for over 70 percent of the time, making it an ideal candidate for wind power $[5,6]$.

The Industrial Technology Research Institute, R.O.C. estimates that for at least one-third of every year wind turbines could be generating electricity at full capacity, with a capacity factor - the ratio of actual productivity in a year to the theoretical maximum - of nearly 45 percent, an efficiency level far exceeding that for major wind power production countries such as Germany and the U.K., and almost twice the annual global average of 23 percent $[5,6]$. 
Therefore, to reduce the GHG emission from energy sector in Penghu Island, wind power is the most efficient measure. Other renewable energy, such as photovoltaic, can further reduce the GHG emissions, and thus is also applied in the plan.

Renewable energy is an intermittent energy source. In winter, wind power can generate more electricity than the required consumption; however, in summer, when the energy consumption peaks, wind speed is relatively low. Wind power cannot always match the energy demand for electricity. Energy-saving measures are thus applied to reduce the peak loads, which include LED street lights, energy-saving appliances, smart meters and low-carbon buildings.

Although transportation is the most important GHG emission source, the major part of the GHG emissions is contributed by fishing boats which is relative difficult to transform the energy usage. Furthermore, electric vehicles are still too expensive for local residents. Therefore, the major measure adopted in transportation sector is to promote electric scooters for local commuting and tourism activities.

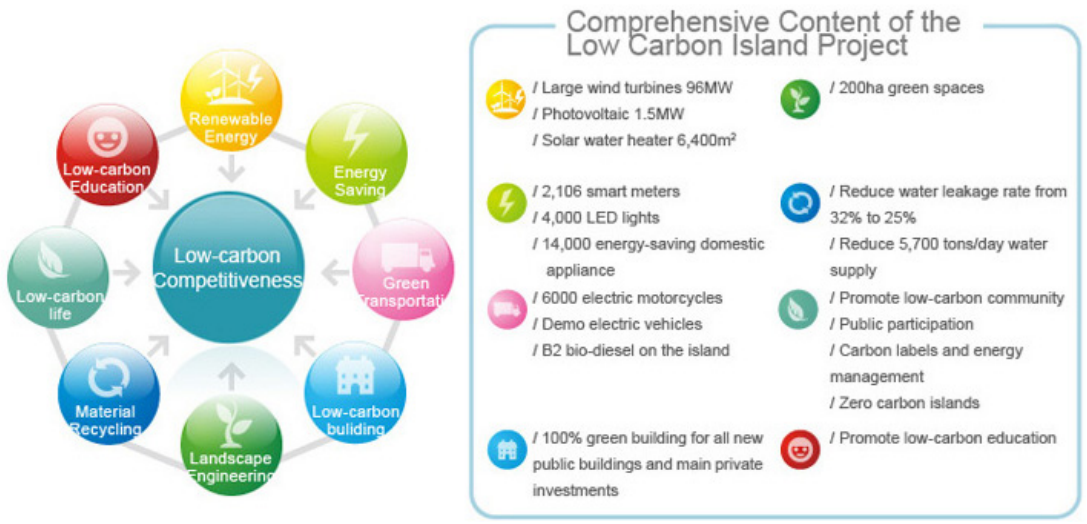

Figure 5: Goals of the low-carbon island project.

A low-carbon transformation plan for the island is finally formulated by further integrating other possible measures. There are eight aspects of the plan, as illustrated in fig. 5, and these aspects are introduced briefly as follows.

1. Renewable energy: The project will take advantage of the local natural resources, such as wind and solar energy. Total capacity of 96MW wind turbines will be constructed. Iconic photovoltaic structures with $1.5 \mathrm{MW}$ capacity will be installed at major attractive sites of Penghu Island. $6,400 \mathrm{~m}^{2}$ solar water heaters will be installed by residents. A Renewable Energy Exhibition Park will be introduced to exhibit various kinds of renewable energy technologies for education and tourism.

2. Energy saving: 2,160 smart meters, 4,000 LED street lights, and 14,000 energy-efficient appliances will be installed or introduced to improve energy efficiency. 
3. Green transportation: 6,000 electric scooters will be introduced to replace traditional scooters. All fuels for transportation will be supplied by $\mathrm{B} 2$ bio-diesel.

4. Low carbon building: All newly constructed public structures and all large scale private constructions should attain green building certifications.

5. Forestation: Increase 200 Hectare green areas.

6. Resource recycling: All recyclable wastes will be reused to reduce the total waste of the island, and a zero-waste facility will be installed to completely eliminate waste export to Taiwan. Water leakage rate will be reduced from $32 \%$ in 2010 to $25 \%$ by installing DMAs in the water distribution network. Underground water reservoirs will be constructed to increase water resources.

7. Low carbon life: Regular promotion activities will be conducted to deliver the importance of low-carbon life style to local residents in hope of increasing public participation in the project. A low-carbon tourism environment will be gradually established by introducing low-carbon facilities and schemes into hotels and restaurants. Four zero-carbon isles will be constructed.

8. Low carbon education: Low-carbon related materials will be introduced in schools throughout the communities.

All the above related plans will be carried out in 5 years (from 2011 to 2015) and eventually achieved the goals of the Penghu Low Carbon Island Project.

\section{Key features}

\subsection{Undersea cable}

Although Penghu Island is an ideal wind farm, high penetration rate of wind power in an isolated grid system will lead to an unstable system. Therefore, the penetration rate of wind power in a grid is usually suggested to under $20 \%[7,8]$. The average loads of Penghu Island are about 59MW in summer and $45 \mathrm{MW}$ in winter. Without necessary facilities, the installation of 96MW wind turbines will thus not only unstabilize the grid system but also blackout the system frequently. Therefore, an undersea cable will be constructed to connect the grid in Penghu Island to the larger grid in Taiwan to stabilize the system, as shown in fig. 6 . During winter, the surplus electricity from wind power can be distributed to Taiwan, and the deficit electricity during summer can also be supplied by power stations in Taiwan.

\subsection{Energy Corporation}

Although wind power can reduce GHG emissions significantly in Penghu Island, there are environmental impacts of wind turbines, including noise pollution, ecological impacts and etc. Noise pollution is the most concerning factor for wind turbine installation. In Taiwan, the regulated minimum distance between 


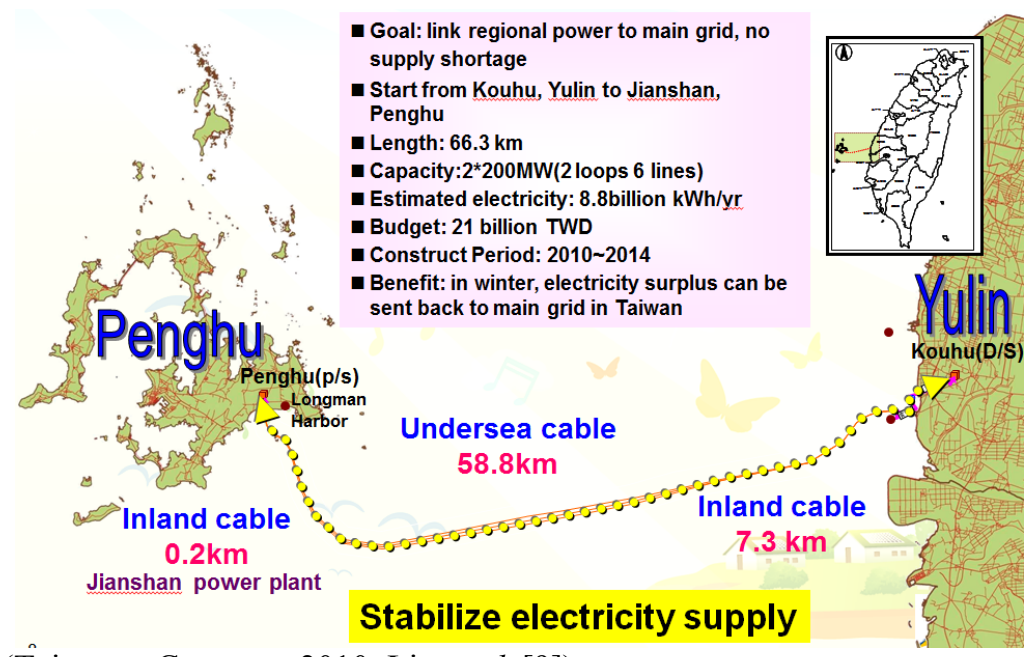

(Taipower Company 2010; Lin et al. [9])

Figure 6: Undersea cable between Penghu and Taiwan.

wind turbines and residences is $500 \mathrm{~m}$. However, residents residing farther than $500 \mathrm{~m}$ still complaint the noise problem frequently. It is inevitable to provoke opposition for the installation of 48 wind turbines in the low-carbon island project.

To mitigate the opposition from residents and to increase the revenue of the county government, the county government plans to raise NT\$3.8 billion $(\sim 127$ million USD) of capital to establish a company, dubbed "Pescadores Energy Tech Co., Ltd.," to sell electricity from wind power back to Taiwan when surplus electricity is available. The county government plans to own $49 \%$ stake in the company, with the remaining $51 \%$ open to subscription by county citizens and investors possessing related technologies. To encourage subscription by county citizens, they will be allowed to exchange their plots of land for the company's shares, for the installation of wind-power generating equipment, and will be given a free share for the subscription of one share. This mechanism can make both the Penghu County Government and local residents become stakeholders in the project. The strength of opposition from local residents can be alleviated $[5,10-12]$.

\subsection{Execution framework}

The low-carbon island project includes various measures executed by many central government agencies. An execution framework has thus been established to monitor the progresses and coordinate the Penghu County Government and other central government agencies. A Penghu Low Carbon Island Construction Project Progress Meeting has been held every season since March 2011. The framework is addressed briefly below. 
1. The Deputy Minister of the Ministry of Economic Affairs, R.O.C. is the chairman of the progress meeting, overseeing the progress of the entire project and also serving as the coordinator of cross-departmental affairs.

2. The Deputy Mayor of the Penghu County serves as the deputy chairman, responsible for the supervision of related plans and works executed by various departments of the Penghu County Government.

3. Each government department involved appoints an executive of a certain level to coordinate, supervise, and monitor related works and attend related meetings.

\section{Conclusions}

As an international society member, Taiwan government is devoted to reducing GHG emissions in recent years with the target of decreasing GHG emissions back to 2005 by 2020 . To achieve the GHG reduction target, various low-carbon technologies and measures should be adopted properly in local areas. Therefore, Penghu Island is chosen as a low-carbon pilot island to demonstrate how to attain the low-carbon future in Taiwan. As a result, a Low-Carbon Penghu Island project has been proposed to reduce $60 \%$ of business-as-usual (BAU) GHG emissions by 2015 . The major measure of the project is to install $96 \mathrm{MW}$ wind turbines to supply all electricity demands in Penghu Island. Eight aspects of measures are adopted in the plan, including renewable energy, energy-saving, green transportation, low-carbon building, forestation, resource recycling, lowcarbon life and low-carbon education.

The expected benefits of the low-carbon island plan are listed as follows and illustrated in fig. 7.

- By 2015, total carbon emission will be $60 \%$ less than BAU in that year and $50 \%$ less than that of 2005 .

- $\quad$ Electricity generated by renewable energy exceeds local demands.

- GHG emission per capita drops from 5.4 tons per capita per year (2008) to 2.1 tons per capita every year (2015).

- With annual revenue of NT\$1.06 billion/year ( $\sim 35$ million USD/year), total investment will be recovered in 6.8 years.

- $\quad$ Further promotion of local tourism industry of Penghu Island.

The GHG reduction target of the low-carbon island project is even better than most of other islands and cities.

- Nation-wide, Taiwan: back to the level in 2005 by 2020

- Jeju Island, Korea: $30 \%$ below BAU by 2020

- Miyakojima (city in an island), Japan: 30\% 40\% below 2003 by 2030

- Rhode Island, United States: $10 \%$ below 1990 by 2020

- Samsø island, Denmark: $100 \%$ by 2003

- Tokyo, Japan: $25 \%$ below 2000 by 2020

- Seoul, Korea: $25 \%$ less than BAU by 2020

- London, United Kingdom: 60\% below 1990 by 2025 


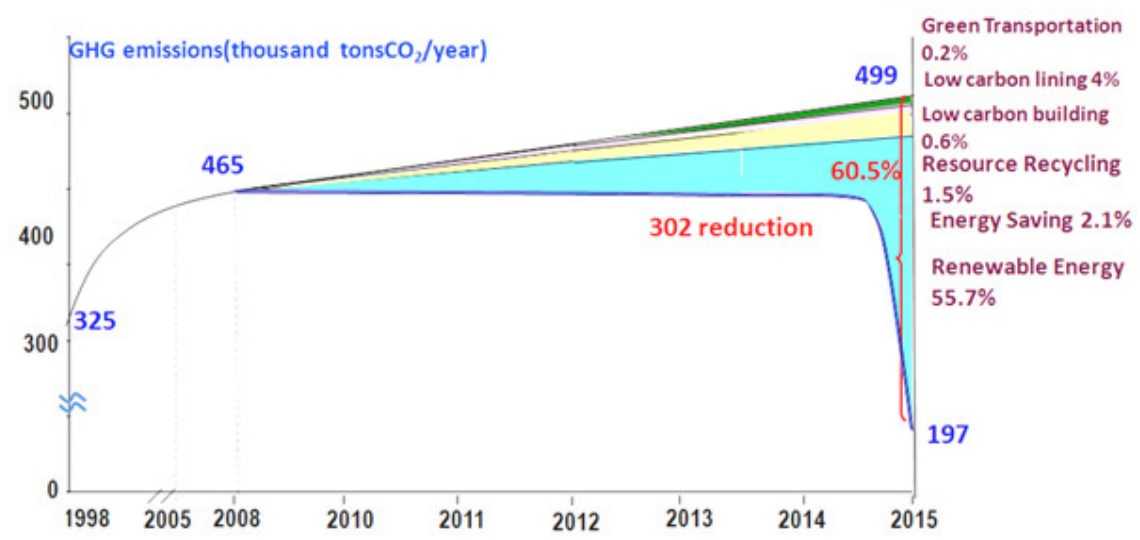

Figure 7: Forecasted reduction of GHG emissions before 2015 with the lowcarbon island project.

After the completion of the low-carbon island project, Penghu Island will be one of the most low-carbon islands in the world with more than $56 \%$ of energy provided by renewable energy and GHG emissions of 2.1 tons- $\mathrm{CO}_{2} \mathrm{e} /$ capita-year. Energy-saving technologies and appliances will be adopted widely on the island, including LED streetlights and energy-saving air conditioners. Water will be sufficient to provide the total consumption of local residents and numerous tourists. The waste will be recycled completely in the island. The second largest industry, tourism, will be further boosted for the transformed low-carbon impression of the island and draw more tourists to the island. Local residents can expect a lifestyle of health and sustainable in the future.

Public participation is one of the key issues for the success of the project. Many measures of the proposed plans require public participation, including electric scooters, energy-saving appliances and solar heaters. Therefore, it is critical to educate the local residents to transform their behavior and willingness to cooperate.

Furthermore, the measures of the project should be reviewed continuously for the unforeseen difficulties encountered during execution. Therefore, the implementation approaches might have to be adjusted accordingly. Innovative approaches should also be developed to resolve the current limitations of technologies and regulations.

\section{Acknowledgement}

The financial support provided by Bureau of Energy (Grant No.101-D0110) is gratefully acknowledged. 


\section{Reference}

[1] Japan External Trade Organization, Eco-Model Cities for a Low-Carbon Society, The Promotion Council of the Low Carbon Cities. http://www.jetro.org/content/807/

[2] Wikipedia, Jeju Smart Grid Demonstration Project in Korea. http://en.wikipedia.org/wiki/Jeju_Smart_Grid_Demonstration_Project in

\section{Korea}

[3] ICLEI, International Local Government GHG Emissions Analysis Protocol, Version 1.0, ICLEI, City of Copenhagen, 2010.

[4] IPCC, 2006 IPCC Guidelines for National Greenhouse Gas Inventories. Intergovernmental Panel on Climate Change, Geneva, Switzerland, 2006.

[5] Industrial Technology Research Institute (ITRI), Environmental Construction and Integrated Application of Low-Carbon Energy Project(99) Final Report, Bureau of Energy, Ministry of Economic Affairs, Taipei, R.O.C., 2010.

[6] Wind Power Sets Penghu on the Right Course, Taiwan Today, Government Information Office, R.O.C. http://taiwantoday.tw/ct.asp? $\underline{x I t e m}=158641 \&$ ctNode $=413$

[7] F. Fesquet, P. Juston, and I. Garzulino, Impact and limitation of wind power generation in an island power system, IEEE Power Tech Conference Proc 3 Bologna, June, 2003.

[8] Wind Power, Wikipedia Foundation Inc., http://en.wikipedia.org/ wiki/Wind power

[9] Lin C.-J., Chu, C.-C., Chang, C.-L., Liu, Y.-H. \& Chuang, Y.-F., (2011), "Impacts on the Transmission Grid for Integrations of Renewable Energy in Taiwan", IEEE PES General Meeting, July 24-28, 2011.

[10] Penghu County Gov't Plans to Found a Large Wind-Power Company, Taiwan Economic News, China Economic News Service. http://cens.com/cens/html/en/news/news inner_35715.html

[11] Penghu Launches NT\$8bn Wind Power Plant Project, Taipei Times, The Taipei Times. http://www.taipeitimes.com/News/taiwan/archives/ 2011/03/24/2003498988

[12] Academic Talk up Penghu's Wind Power Credentials, Taiwan Today, Government Information Office, R.O.C. http://taiwantoday.tw/ct.asp? $\underline{\mathrm{xItem}}=182711 \& \mathrm{CtNode}=436$ 